\section{Gender, Science and Innovation}

\section{New Perspectives}

Edited by Helen Lawton Smith, Birkbeck University of London, UK, Colette Henry, Head of the Department of Business Studies, Dundalk Institute of Technology, Republic of Ireland and Adjunct Professor of Entrepreneurship, UiT The Arctic University of Norway, Tromsø, Norway, Henry Etzkowitz, President, Triple Helix Association and Alexandra Poulovassilis, Department of Computer Science and Information Systems, Birkbeck, University of London, UK

Gender, Science and Innovation explores the contemporary challenges facing women scientists in academia and develops effective strategies to improve gender equality. Addressing an important gap in current knowledge, chapters offer a range of international perspectives from diverse contexts, countries and institutional settings. This book is an essential contribution to the literature for academics, researchers and policy makers concerned with improving gender equality in academia and seeking to learn from the experiences of others.

'Lucid, compelling evidence on the need for systemic change within academia and scientific research institutions to make the most of women's talents.'

- Helen Wollaston, Chief Executive, WISE

'A comprehensive collection of articles on women scientists in academia at various stages of careers in science and on women in medicine and innovation, interrogating structures and gender equality programs, this book provides a rich insight and a thorough update on the current situation of women in science.'

- Namrata Gupta, IIT Kanpur Campus, India

This book turns a timely spotlight on gender imbalances and the stalled gender revolution in the academic science field, including technical entrepreneurship. Comprehensive case exemplars and strategic insights make it a must-read not only for researchers with interest in the field, but also for all those seeking inspiration on how to advance gender equality in the sciences and academia.'

- Anne de Bruin, Massey University, New Zealand

'This collection is a compelling read for those interested in the state of gender relations in the science and innovation domains. Its critical feminist stance challenges the reader to reflect on the nature and causes of gender inequality and, more importantly, the cultural shift required to address these imbalances.'

- Maura McAdam, DCU Business School, Republic of Ireland

\section{How To Order}

\section{Online}

www.e-elgar.com

Get up to $20 \%$ discount when you order online

\section{By Email}

UK/ROW: sales@e-elgar.co.uk

N/S America: elgarsales@e-elgar.com

\section{By Phone}

UK/ROW: $\underline{+44}$ (0) $\underline{1242226934}$

N/S America: +1 413-584-5551

\section{Connect With Us}

\section{Find us on Facebook}

facebook.com/EdwardElgarPublishing

\section{Follow us on Twitter}

For news, views and offers

@ElgarPublishing

\section{Read our Blog}

For news, views and debate from our authors and readers.

https://www.elgar.blog

\section{For More Information}

UK/ROW: info@e-elgar.co.uk

N/S America: elgarinfo@e-elgar.com

\section{0 $432 \mathrm{pp}$ \\ Hardback \\ 9781786438966 \\ $£ 103.50 \quad £ 115.00$ \\ $\$ 762.00 \quad \$ 180.00$}

\section{Elgaronline 9781786438973}

